\title{
Long-Acting Inhaled Bronchodilators: The Mainstay of COPD Management
}

Peter J. Barnes, DM, DSc, FRCP, FMedSci, FRS

National Heart \& Lung Institute, Imperial College, London, UK

\section{ABSTRACT}

Long-acting bronchodilators are the most effective treatments currently available for managing patients with COPD. Long-acting muscarinic antagonists and $\beta_{2}$-agonists are equally effective in producing bronchodilation, reducing symptoms, improving quality of life, and preventing exacerbations and are well tolerated. They probably work mainly by relaxing smooth muscle of peripheral airways to reduce gas trapping. Although both drug classes have non-bronchodilator effects that might be beneficial, this has not been clearly established in COPD patients. Remarkably, long-acting $\beta_{2}$-agonists and long-acting muscarinic antagonists have additive bronchodilator effects, although this has not always translated into greater clinical benefit. Nevertheless, long-acting $\beta_{2}$-agonist/long-acting muscarinic antagonist fixed-dose combinations are more effective than the single components and inhaled-corticosteroid/long-acting $\beta_{2}$-agonist combinations. Although there is some rationale for triple therapy with long-acting $\beta_{2}$-agonist/long-acting muscarinic antagonist/inhaled-corticosteroid, it remains to be shown that this would be more effective than long-acting $\beta_{2}$-agonist/long-acting muscarinic antagonist combinations, although may be indicated for COPD patients with frequent exacerbations and with overlapping features with asthma, including increased blood eosinophils. It is unlikely that new classes of bronchodilators will be developed for COPD and what is needed is effective and safe antiinflammatory treatments. (BRN Rev. 2016;2:201-14)

Corresponding author: PJ Barnes, p.j.barnes@ic.ac.uk

Key words: Fixed dose combination inhaler. Long-acting $\beta 2$-agonist (LABA). Long-acting muscarinic antagonist (LAMA). Triple inhaler. 


\section{INTRODUCTION}

Bronchodilators are the mainstay of current drug therapy for COPD, although the degree of bronchodilation is less than seen in asthma, typically about $5-10 \%$ improvement in forced expiratory volume in one second ( $\left.\mathrm{FEV}_{1}\right)$, although some patients show greater responses. However, bronchodilators may improve dyspnoea and exercise tolerance, despite little or no effect on spirometry, by reducing lung volumes by reducing hyperinflation (gas trapping). In addition, bronchodilators may improve mucociliary clearance. The choice of bronchodilator includes short- and long-acting $\beta_{2}$-agonists, anticholinergics (muscarinic receptor antagonists) and high doses of theophylline, and will partly be determined by patient preference and cost. The preferred bronchodilators are long-acting inhaled drugs such as long-acting $\beta_{2}$-agonists (LABA) or long-acting muscarinic antagonists (LAMA) and several are now available for $\mathrm{COPD}^{1}$ (Table 1).

\section{MECHANISMS OF ACTION}

It is likely that the major site of action of longacting bronchodilators in COPD is small-airway smooth muscle, and that reducing cholinergic tone reduces airway closure on expiration, thereby reducing lung volumes and gas trapping, particularly on exertion (dynamic hyperinflation) and thus improving exercise tolerance ${ }^{2}$. Long-acting bronchodilators are more clinically effective than short-acting bronchodilators. The LAMA tiotropium bromide has a greater bronchodilator effect than ipratropium bromide four times daily, although the peak bronchodilator effect is similar. Ipratropium wears off completely before the next dose, whereas with tiotropium the bronchodilation is maintained over 24 hours ${ }^{3}$. Sustained bronchodilation is more effective in reducing symptoms and improving the quality of life in COPD patients. Similarly the once-daily LABA indacaterol is more effective than salmeterol and formoterol given twice daily ${ }^{4,5}$ and tiotropium once daily is more effective than salmeterol twice daily ${ }^{6}$, whereas once-daily indacaterol, tiotropium, and glycopyrrolate have equivalent bronchodilator effects ${ }^{7}$. An unexpected benefit of longacting bronchodilators in COPD patients is the reduction in exacerbations, which was discovered when long-acting bronchodilators, either LABA or LAMA, were given over a period of 12 months or more. This was first demonstrated with tiotropium by chance ${ }^{3}$ and then confirmed in a study where reduction in exacerbations was the primary outcome ${ }^{8}$. The mechanisms for the reduction in exacerbations by long-acting bronchodilator therapy was thought to be due to the possible anti-inflammatory effects of these medications, but this has never been consistently documented with either LABA or LAMA in COPD patients'. A more likely explanation is that long-acting bronchodilators stabilize airways so that when exacerbations are induced by viral or bacterial infections, the airways are less likely to constrict.

\section{LONG-ACTING MUSCARINIC ANTAGONISTS}

Atropine is a naturally occurring compound that was introduced for the treatment of asthma but, because of side effects (particularly drying of secretions and central nervous system (CNS) effects), less soluble quaternary 
TABLE 1. Inhaled long-acting bronchodilators for COPD

\begin{tabular}{|c|c|c|c|}
\hline Drug & Dose (pg/puff)* & Formulation & Frequency \\
\hline \multicolumn{4}{|l|}{ LABA } \\
\hline Formoterol & $6-12$ & MDI/DPI & bid \\
\hline Salmeterol & 25 & MDI/DPI & bid \\
\hline Indacaterol & 75 & DPI & $q d$ \\
\hline Vilanterol & 25 & DPI & qd \\
\hline Olodaterol & 2.5 & SMI & qd \\
\hline \multicolumn{4}{|l|}{ LAMA } \\
\hline Tiotropium & 18 & $\mathrm{DPI} / \mathrm{SMI}$ & qd \\
\hline Glycopyrrolate & 50 & DPI & qd \\
\hline Umeclidinium & 62.5 & DPI & qd \\
\hline Aclidinium & 400 & DPI & bid \\
\hline \multicolumn{4}{|l|}{ LABA/LAMA FDC } \\
\hline Indacaterol/glycopyrrolate (Ultibro ${ }^{\circledR}$ ) & $100 / 50$ & DPI & qd \\
\hline Vilanterol/umeclidinium (Anoro ${ }^{\circledR}$ ) & $22 / 55$ & DPI & bid \\
\hline Olodaterol/tiotropium (Spiolto ${ }^{\circledR}$ ) & $2.5 / 2.5$ & SMI & qd \\
\hline Formoterol/glycopyrrolate (Bevespi ${ }^{\circledR}$ ) & $4.8 / 9$ & DPI & bid \\
\hline Formoterol/aclidinium (Duaklir ${ }^{\circledR}$ ) & $12 / 340$ & DPI & bid \\
\hline \multicolumn{4}{|l|}{ ICS/LABA FDC } \\
\hline Fluticasone propionate/salmeterol (Seretide ${ }^{\circledR} /$ Advair $^{\circledR}$ ) & $500 / 50$ & MDI/DPI & bid \\
\hline Budesonide/formoterol (Symbicort ${ }^{\circledR}$, DuoResp ${ }^{\circledR}$ ) & $400 / 12$ & MDI/DPI & bid \\
\hline BDP/formoterol (Foster ${ }^{\circledR}$ ) & $100 / 6$ & MDI/DPI & bid \\
\hline Fluticasone propionate/formoterol (Flutiform ${ }^{\circledR}$ ) & $400 / 12$ & MDI & bid \\
\hline Fluticasone furoate/vilanterol (Relvar ${ }^{\circledR} /$ Breo $\left.^{\circledR}\right)$ & $200 / 25$ & DPI & qd \\
\hline \multicolumn{4}{|l|}{ ICS/LABA/LAMA FDC (Triple) } \\
\hline Budesonide/formoterol/glycopyrrolate (BFG) ${ }^{85}$ & $?$ & MDI & bid \\
\hline BDP/formoterol/glycopyrrolate ${ }^{86}$ & $100 / 6 / 12.5$ & MDI/DPI & bid \\
\hline Fluticasone furoate/vilanterol/umeclidinium & $?$ & DPI & $q d$ \\
\hline Mometasone/indacaterol/glycopyrrolate (OVM149) & $?$ & DPI & qd \\
\hline
\end{tabular}

${ }^{*}$ Dose of drug base leaving mouthpiece.

BDP: beclomethasone dipropionate; bid: twice daily; DPI: dry powder inhaler; FDC: fixed dose combination; ICS: Inhaled corticosteroid; LABA: Iong-acting $\beta_{2}$-agonist;

LAMA: long-acting muscarinic antagonist; MDI: metered dose inhaler; qd: once daily; SMI: soft mist inhaler.

compounds (e.g. ipratropium bromide) were developed. Subsequently, tiotropium was discovered, which, although of similar chemical structure to ipratropium, was found to have an unexpectedly long duration of action ${ }^{9}$. Anticholinergics are probably the most effective bronchodilators in the treatment of COPD, and vagal cholinergic tone appears to be the 


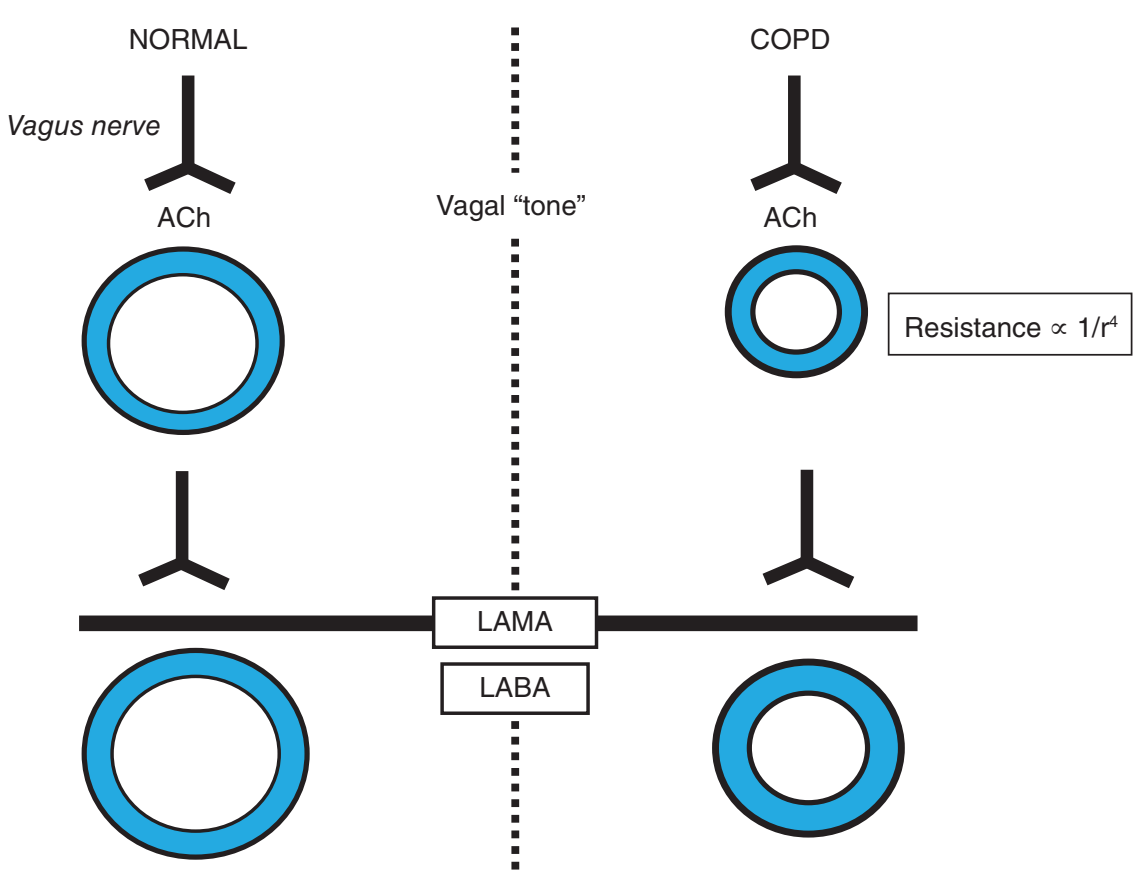

FIgURE 1. Long-acting bronchodilator mechanisms in chronic obstructive pulmonary disease (COPD).

Normally there is a certain amount of cholinergic tone. This is exaggerated in COPD because of geometric factors related to the fixed narrowing of the airways (airway resistance $R$ is proportional to $1 / r^{4}$, where $r$ is airway radius), so that airway resistance improves to a greater extent than in normal airways with a long-acting muscarinic antagonist, which blocks the effect of acetylcholine on muscarinic receptors in airway smooth muscle. Long-acting $\aleph_{2}$-agonists block all known bronchoconstriction mechanisms, but have a similar effect to long-acting muscarinic antagonists, suggesting that vagal tone is the only reversible component in COPD.

Ach: acetylcholine; LABA: long-acting $\aleph_{2}$-agonist; LAMA: long-acting muscarinic antagonist.

only reversible element in the airflow obstruction of COPD since muscarinic antagonists are equally effective to $\beta_{2}$-agonists that reverse any bronchoconstrictor tone.

\section{Mode of action}

Long-acting muscarinic antagonists are specific antagonists of muscarinic receptors and inhibit cholinergic nerve-induced bronchoconstriction
(Fig. 1). Currently available LAMA selectively target $M_{3}$ and $M_{1}$ muscarinic receptors in the airways. The major bronchodilator effect is through antagonising $M_{3}$ receptors, which are expressed on smooth muscle cells of all airways ${ }^{10}$. Tiotropium has a prolonged inhibitory effect on cholinergic nerve-induced contraction of human airways in vitro and, after washing, persists for 15 hours compared with ipratropium, which persists for only 1-2 hours ${ }^{11}$. Human airway smooth 
muscle also expresses $M_{2}$ receptors, which inhibit cyclic adenosine monophosphate (AMP) accumulation and so antagonise the effects of $\beta_{2}$-agonists, but these are believed to play little functional role in regulating airway smooth muscle tone ${ }^{12}$. The $\mathrm{M}_{2}$ receptors on postganglionic nerves in the airways inhibit the release of acetylcholine and act as inhibitory auto-receptors, so that blocking $\mathrm{M}_{2}$ receptors increases acetylcholine release and reduces the effect of competitive antagonism of $\mathrm{M}_{3}$ receptors $^{13}$. The LAMA, such as tiotropium bromide and glycopyrrolate (glycopyrronium bromide), have a long duration of action on human $M_{3}$ receptors, but a much shorter duration of action on $\mathrm{M}_{2}$ receptors, so that they have a kinetic selectivity ${ }^{9,14-16}$. The $M_{1}$ receptors are expressed mainly on submucosal glands, where they mediate mucus secretion, and on parasympathetic ganglia, where they enhance ganglionic transmission and therefore reflex bronchoconstriction. Tiotropium and glycopyrrolate have a relatively long duration at these receptors and this may contribute to their favourable effects in COPD.

A small degree of resting bronchomotor tone is present because of tonic cholinergic nerve impulses, which release acetylcholine in the vicinity of airway smooth muscle, and cholinergic reflex bronchoconstriction may be initiated by irritants, cold air and stress. The LAMA reduce gas trapping by acting on small airways $^{12}$ and thereby improve dyspnoea and symptoms with improvement in exercise tolerance $^{17}$. In peripheral airways there are few cholinergic nerves, which has suggested that peripheral cholinergic tone may be due to release of acetylcholine from extra-neuronal sources such as airway epithelial cells and even inflammatory cells ${ }^{18}$. Cholinergic tone may be increased in COPD due to increased expression of muscarinic receptors ${ }^{19}$ as well as increased release of acetylcholine from non-neuronal sources.

Muscarinic receptors, including $\mathrm{M}_{3}$ receptors, are expressed on several inflammatory cells, including macrophages, neutrophils, and $\mathrm{T}$ lymphocytes, suggesting that LAMA might have anti-inflammatory effects ${ }^{20}$. For example, alveolar macrophages express $M_{2}$ and $M_{3}$ receptors and acetylcholine stimulates the release of the neutrophil chemotactic factor leukotriene $(\mathrm{LT})-\mathrm{B}_{4}{ }^{21}$. In an animal model of COPD (cigarette smoke-exposed mice) tiotropium reduces neutrophilic inflammation, with concomitant reduction of $\mathrm{LTB}_{4}$ IL-6, and $\mathrm{KC}$ (murine CXCL8) ${ }^{22}$. Muscarinic receptors are also expressed on fibroblasts, and acetylcholine has a profibrotic effect that is blocked by tiotropium ${ }^{23-25}$. The $\mathrm{M}_{3}$ receptors on airway smooth muscle cells also stimulate proliferation, suggesting that LAMA may reduce structural remodelling of airways. Tiotropium also has an unexpected inhibitory effect on transient receptor potential V1 (TRPV1) channels that are involved in airway sensory nerve activation and this could explain its beneficial effect on cough ${ }^{26}$. Interestingly, tiotropium also reduces rhinovirus infection of airway epithelial cells via an inhibitory effect on intercellular adhesion molecule 1 (ICAM-1), which acts as a receptor for this virus, so this could contribute to the reduction in infective exacerbations by LAMA ${ }^{27}$. However, despite these interesting observations on the nonbronchodilator effects of tiotropium, there is so far no convincing evidence that LAMA have significant anti-inflammatory effects in COPD patients. 


\section{Clinical studies in COPD}

Tiotropium bromide is a very effective oncedaily bronchodilator in COPD patients that has minimal side effects at the normally recommended doses ${ }^{28}$. It is given by a dry powder inhaler (Handihaler ${ }^{\circledR}$ ) or as a soft mist inhaler (Respimat ${ }^{\circledR}$ ) and gives bronchodilation that carries over to the next day, thus providing persistent bronchodilation ${ }^{3}$. This results in significantly better improvement in the quality of life (St George's Respiratory Questionnaire) than ipratropium bromide given four times daily. Indeed studies with methacholine challenge in asthma patients suggest that its duration of action may be up to 72 hours $^{29}$. Unexpectedly, tiotropium also reduced exacerbations and hospitalisations in long-term studies $^{8}$, which was confirmed in the large UPLIFT study over four years compared to placebo, even when added to other treatments, including LABA and inhaled corticosteroids (ICS) ${ }^{30}$. Overall, tiotropium does not reduce disease progression, but in patients with moderate disease (GOLD2) and in early disease, there is a small reduction in annual decline of $\mathrm{FEV}_{1}$ and forced vital capacity ${ }^{31,32}$.

Several other LAMA have now been developed. Glycopyrrolate is an old drug used systemically to dry airway secretions before anaesthesia and first shown to be a long-acting bronchodilator of similar duration to tiotropium in $2005^{33}$. Glycopyrrolate is usually given once daily and has a very similar profile to tiotropium in COPD patients ${ }^{34-36}$. However, in low doses, glycopyrrolate should be given twice daily ${ }^{37}$. Umeclidinium is another oncedaily LAMA, very similar in profile to tiotropium and glycopyrrolate ${ }^{38}$. Aclidinium is also a LAMA, but appears to have a shorter duration than tiotropium so is given twice daily ${ }^{39,40}$. However, aclidinium has a faster onset of action than other LAMA, although this is of no clinical relevance as LAMA are given as regular maintenance therapy rather than for symptom relief as required.

\section{Side effects}

All LAMA have a similar safety profile and are well tolerated in elderly patients with COPD. Dry mouth is seen in approximately $10 \%$ of patients and is due to reduced salivary flow, probably a local effect due to $\mathrm{M}_{1}$ receptor inhibition, but this often disappears with continued use. There are occasional reports of urinary retention and there is a theoretical risk of glaucoma. Some studies were interpreted as showing increased cardiovascular mortality with tiotropium, particularly when given by soft mist inhaler (Respimat $\left.{ }^{\circledR}\right)^{41}$. However, cardiovascular mortality was significantly reduced in the UPLIFT study using dry powder inhaler, and was not increased in a large safety study using Respimat ${ }^{\circledR 42}$.

\section{LONG-ACTING ß2-AGONISTS}

Short-acting $\beta_{2}$-agonists are used mainly for symptom relief as required, but may be used four times a day on a regular basis. However, LABA are preferred as they give better control of symptoms and are used as a maintenance therapy.

\section{Mode of action}

The $\beta_{2}$-agonists have several potential beneficial effects on the airways in $\mathrm{COPD}^{43}$. These 


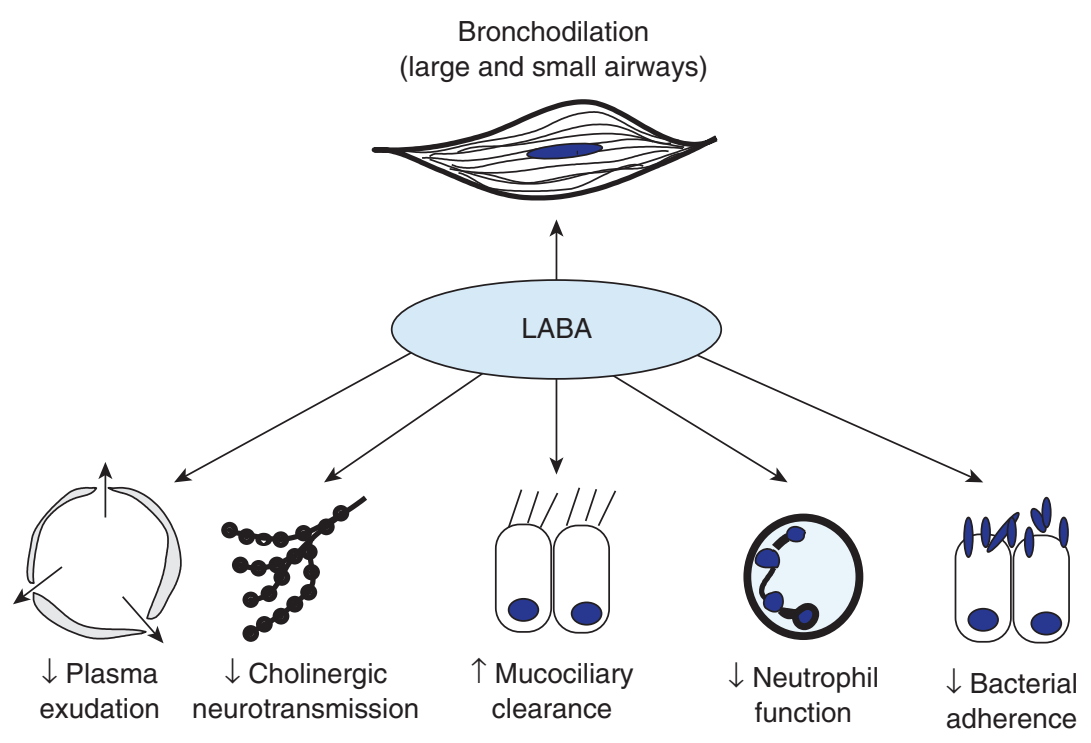

FIgURE 2. Mechanism of action of long-acting $ß_{2}$-agonists in COPD.

Although their primary action is likely to be on airway smooth muscle, there are additional effects of $\beta_{2}$-agonists that may be beneficial. LABA: long-acting $ß_{2}$-agonist.

drugs act directly on $\beta_{2}$-adrenoceptors on airway smooth muscle, causing a relaxation in large and small airways. They act as functional antagonists and reverse bronchoconstriction, irrespective of cause. They also have several non-bronchodilator effects that may potentially contribute to their clinical benefit in COPD (Fig. 2). Experimentally, they reduce plasma exudation and cholinergic reflexes. They also increase mucociliary clearance (when it is reduced). Evidence suggests that $\beta_{2}$-agonists may reduce adherence of bacteria to airway epithelial cells and this may contribute to their reduction of infective exacerbations ${ }^{44}$. There is some evidence that $\beta_{2}$-agonists may increase the ventilatory drive to hypercapnia (but not to hypoxia). It is still uncertain whether LABA have long-term anti-inflammatory effects in COPD, and any anti-inflammatory effects on inflammatory cells are usually rapidly tachyphylactic. However, formoterol significantly reduces sputum neutrophils in patients with neutrophilic asthma by inhibiting the release of the neutrophil chemoattractant CXCL8 from airway epithelial cells ${ }^{45}$. This anti-neutrophil effect has not yet been demonstrated in COPD patients, however.

\section{Clinical use}

Salmeterol and formoterol give bronchodilation and protection against bronchoconstriction for over 12 hours. Nebulised formoterol, including the active enantiomer (arformoterol) is also effective in COPD, but it is only 
available in the USA ${ }^{46,47}$. Indacaterol and olodaterol are once-daily LABA that are now approved for use in COPD and have a similar efficacy and safety profile ${ }^{48,49}$. Vilanterol is another once-daily LABA, but not yet approved as monotherapy. Once-daily LABA are more effective than twice-daily LABA, supporting the view that maintained bronchodilation is beneficial. LABA improve symptoms, quality of life, and exercise performance and reduce air trapping through relaxant effects on small airways ${ }^{50}$. In long-term studies they reduce exacerbations and may reduce mortality ${ }^{51,52}$. They have a similar efficacy to LAMA, although once-daily tiotropium is more effective than twice-daily salmeterol in preventing exacerbations and hospitalisation ${ }^{6}$. However, as discussed above, once-daily tiotropium and glycopyrrolate are similar to once-daily indacaterol $^{7}$.

\section{Side effects}

Side effects are not usually a problem with LABA in COPD, even with hypoxia and cardiovascular comorbidity ${ }^{50}$. A large study recently showed that even in COPD patients with cardiovascular risk, there was no increase in cardiovascular events after treatment with once-daily vilanterol ${ }^{54}$. Muscle tremor (direct effect on skeletal muscle $\beta_{2}$-receptors) is more common in elderly patients, but tends to disappear through development of tolerance with time. Tachycardia (direct effect on atrial $\beta_{2}$-receptors and reflex effect from increased peripheral vasodilatation via $\beta_{2}$-receptors) may cause palpitations, but tolerance usually develops. Hypokalaemia is a direct effect on skeletal muscle uptake of potassium ions via $\beta_{2}$-receptors, but is usually a small effect. Hypoxaemia due to increased ventilation/perfusion (V/Q) mismatch due to pulmonary vasodilatation is not a problem with chronic treatment.

\section{LONG-ACTING ß2-AGONIST/ LONG-ACTING MUSCARINIC ANTAGONIST FIXED-DOSE COMBINATION INHALERS}

The bronchodilator effects of LABA and LAMA appear to be additive, at least as measured by $\mathrm{FEV}_{1}$. This was demonstrated initially with an additive bronchodilator effect of either formoterol or salmeterol twice daily added to tiotropium once daily ${ }^{55,56}$. Adding indacaterol in patients also treated with tiotropium also shows an add-on bronchodilator effect ${ }^{57}$. In one study, a maximally effective bronchodilator dose of indacaterol was given and, since LABA inhibit all bronchoconstrictor mechanisms, including cholinergic tone, no further bronchodilation should be possible ${ }^{58}$. However, the addition of glycopyrrolate in combination with indacaterol (Ultibro ${ }^{\circledR}$ ) almost doubled the bronchodilator response. It is possible that this is achieved through some effect in addition to reduction in cholinergic tone, such as an effect on mucus hypersecretion, although this is unlikely as the additive effect is seen immediately. Another possibility is that there is some cross-talk between cholinergic and adrenergic signalling pathways in airway smooth muscle cells. Cholinergic tone is mediated via an effect of acetylcholine on $\mathrm{M}_{3}$ receptors on airway smooth muscle cells, which are coupled to phospholipase $C \beta$ (PLC $\beta$ ), which generates the second messenger inositol 3,4,5 trisphosphate $\left(\mathrm{IP}_{3}\right)$ that is responsible for the release of calcium ions from internal stored, resulting in muscle contraction. The 


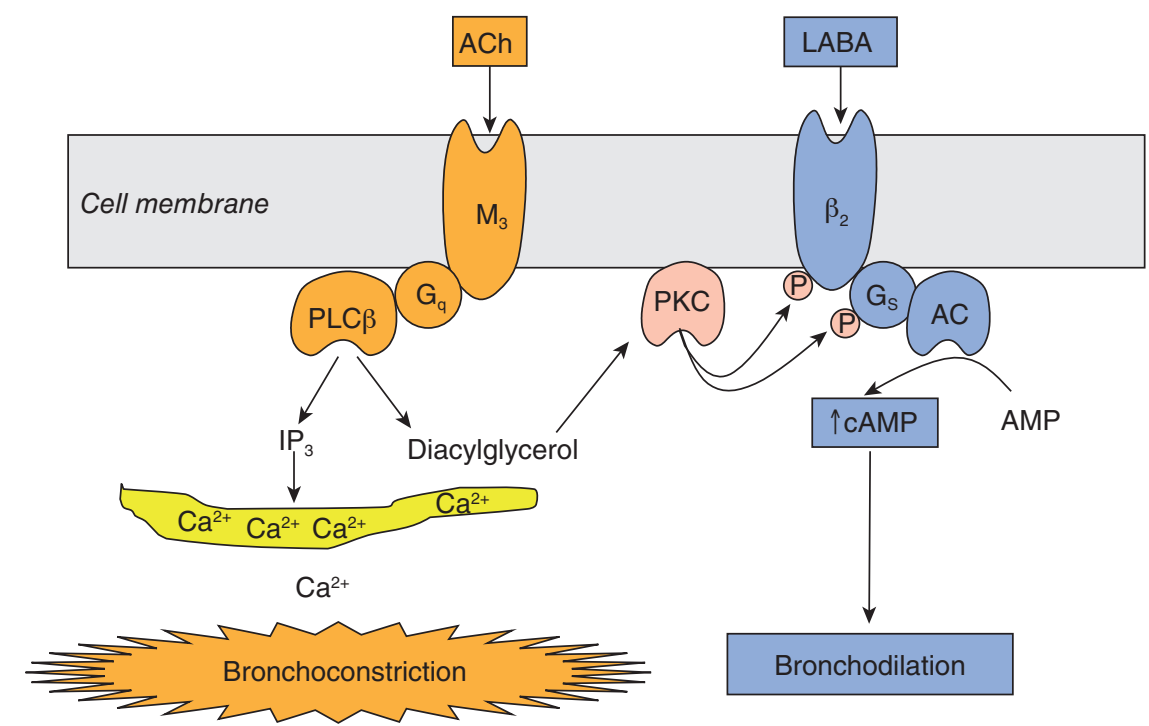

Figure 3. Possible mechanism for additive bronchodilation with long-acting $\aleph_{2}$-agonists plus long-acting muscarinic antagonist. Cholinergic tone activates muscarinic $M_{3}$ receptors in airway smooth muscle cells, leading to activation of phospholipase $C ß$ via the coupling $G$-protein $G_{q^{\prime}}$ which generates inositol trisphosphate that releases calcium ions $\left(\mathrm{Ca}^{2+}\right)$ from intracellular stores, leading to bronchoconstriction. Phospholipase $C ß$ also generates the lipid mediator diacylglycerol, which activates protein kinase $C$ in the cell membrane, which phosphorylates $B_{2}$-adrenergic receptors and $G_{s^{\prime}}$ thus uncoupling them from adenylyl cyclase, thus reducing cyclic adenosine monophosphate and the bronchodilator response to long-acting $\beta_{2}$-agonists. Giving a long-acting muscarinic antagonist at the same time as a long-acting $\aleph_{2}$-agonist prevents the braking effect of the cholinergic pathway, resulting in a greater overall bronchodilator response.

AC: adenylyl cyclase; Ach: acetylcholine; AMP: adenosine monophosphate; Ca: calcium; cAMP: cyclic adenosine monophosphate; $\mathrm{IP}_{3}$ : inositol trisphosphate; LABA: long-acting $\aleph_{2}$-agonist; PKC: protein kinase C; PLCß: phospholipase Cß.

PLC $\beta$ also generates another second messenger, diacylglycerol, which activates membrane-bound protein kinase C (PKC), which is able to phosphorylate both $\beta_{2}$-receptors and the stimulatory G-protein $\left(G_{s}\right)$, resulting in uncoupling of $\beta_{2}$-receptors with reduction in cyclic AMP, which is a braking mechanism for $\beta_{2}$-agonist induced bronchodilation ${ }^{59}$. By adding an $\mathrm{M}_{3}$ antagonist, this braking effect would be relieved, thus giving a larger bronchodilator effect of the $\beta_{2}$-agonist (Fig. 3).
The additive bronchodilator effect is also seen after chronic dosing, with a reduction in

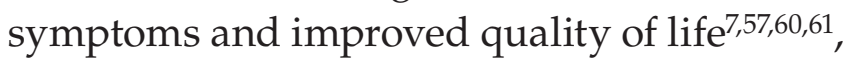
but far less than additive effects in preventing exacerbations ${ }^{60}$. Recently, several other LABA/ LAMA combination inhalers have been developed, including once-daily vilanterol/ umeclidinium (Anoro) and olodaterol/tiotropium (Spiolto), and twice-daily formoterol/ glycopyrrolate (Bevespi) and formoterol/aclidinium (Duaklir) ${ }^{62-64}$. The LABA/LAMA fixeddose combinations have similar effects in terms 
of efficacy and prevention of exacerbations, as shown by a recent network meta-analysis, in the absence of direct head-to-head comparisons $^{65}$. It is likely that LABA/LAMA combination inhalers will become first-line therapy, especially as they appear more effective in reducing symptoms than an ICS/LABA combination ${ }^{66-68}$. Indacaterol/glycopyrrolate once daily is more effective in preventing exacerbations than twice-daily fluticasone propionate/salmeterol, which has been widely used in the initial treatment of COPD in conflict with guideline recommendations ${ }^{69}$.

Side effects do not appear to be a problem with LABA/LAMA combinations as the two classes of drug have different off target effects.

\section{INHALED CORTICOSTEROID/ LONG-ACTING ß2-AGONIST FIXED-DOSE COMBINATION INHALERS}

Several fixed-dose ICS/LABA combination inhalers have been used in COPD patients, including twice-daily fluticasone propionate/ salmeterol (Seretide ${ }^{\circledR}$, Advair ${ }^{\circledR}$ ), budesonide/ formoterol (Symbicort ${ }^{\circledR}$ ), and beclomethasone dipropionate/formoterol $\left(\right.$ Foster $\left.^{\circledR}\right)$, and oncedaily fluticasone furoate/vilanterol (Relvar ${ }^{\circledR}$, Breo $\left.{ }^{\circledR}\right)$ and these combinations are more convenient and may improve adherence. Several studies have demonstrated a benefit of combination inhalers containing a corticosteroid and a LABA in COPD patients ${ }^{70}$. However, most of the benefit seems to be provided by the LABA component ${ }^{52}$. Patients with severe COPD at risk of exacerbations could be withdrawn from ICS therapy without risk of increased exacerbations, suggesting that ICS were not providing any additional value ${ }^{71}$. In the Withdrawal of Inhaled Steroids during Optimized Bronchodilator Management (WISDOM) study, ICS were slowly withdrawn from patients with a history of exacerbations in the previous year without evidence of increased exacerbations, although there was a small fall in $\mathrm{FEV}_{1}{ }^{71}$. In some patients it may be possible to gradually decrease the ICS because the incidence of subsequent exacerbations of patients continued on double bronchodilator therapy is not increased. However, patients with poor lung function should be monitored because some may have significant decrease in lung function that may signal a benefit from the ICS therapy.

Any superiority of combination inhalers over LABA alone in reducing exacerbations may be counteracted by the higher risk of side effects due to the corticosteroid component ${ }^{72}$. The ICS/LABA combination inhalers improve symptoms and reduce exacerbations with a reduction in all-cause mortality, although this does not quite reach statistical significance ${ }^{70}$. The reduction in exacerbation between twicedaily fluticasone/salmeterol is similar to that seen with tiotropium ${ }^{73}$. The ICS/LABA combination inhalers may be useful when patients with $\mathrm{FEV}_{1}<50 \%$ predicted and with frequent exacerbations ( $\geq 2$ /year) who are already on tiotropium need further treatment. The once-daily ICS/LABA combination inhaler (fluticasone furoate/vilanterol, $\operatorname{Relvar}^{\circledR}$ ) has been approved for use in COPD, although there appears little difference in comparison with vilanterol alone ${ }^{74}$ and its effects are similar to twice-daily fluticasone propionate/salmeterol with a similar side effect profile (including increased risk of pneumonia) ${ }^{75}$. However, the fluticasone furoate/vilanterol combination is more effective in reducing exacerbations than 
vilanterol alone if blood eosinophils are $\geq 2 \%$ and particularly $>6 \%$.

Recently, there has been considerable interest in predicting which COPD patients may benefit from ICS added to LABA. There is some evidence that increased blood eosinophils may predict a better clinical response to ICS/LABA in terms of reduced exacerbations. A post hoc analysis of a study that compared fluticasone furoate/vilanterol with vilanterol alone showed a greater effect of the combination in patients

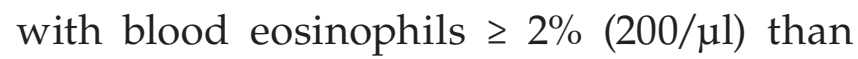
those with $<2 \%$, and the difference was greater the higher the blood eosinophils ${ }^{76}$. However, the absolute number of exacerbations on the combination was unchanged at differing blood eosinophil counts, suggesting that vilanterol may even increase exacerbations. In addition, there were no differences in lung function of symptoms between these treatments at different eosinophil cut-off points. This was supported by three other studies that compared ICS/LABA with tiotropium ${ }^{77}$, but not by a further analysis of the fluticasone furoate/ vilanterol versus vilanterol data ${ }^{78}$. However, a more recent study showed that blood eosinophils did not predict any better responses to fluticasone/salmeterol compared to indacaterol/glycopyrrolate ${ }^{69}$. When ICS are withdrawn, only patients with blood eosinophils $\geq 4 \%$ appear to be at greater risk of increased exacerbations ${ }^{79}$. The importance of blood eosinophils as a marker is uncertain and there may be little relationship to sputum or lung eosinophils.

\section{TRIPLE INHALERS}

Addition of a LAMA to an ICS/LABA inhaler appears to give further improvement in lung function and reduction in exacerbations ${ }^{80-84}$. This has suggested that a triple fixed-dose combination of ICS/LABA/LAMA may be useful and several triple combinations are now in development for COPD ${ }^{86,87}$. Many patients with COPD now end up on triple therapy since their symptoms persist whatever treatment is given. The introduction of triple fixed-dose combination inhalers may therefore be popular, although relatively few patients with COPD benefit from ICS therapy. If patients are started on a LAMA and then proceed to a fixed-dose LABA/LAMA combination, it might be better to then switch to a triple inhaler if there is indication (frequent exacerbations, high blood eosinophil count, clinical features of asthma-COPD overlap) rather than adding an ICS alone as this is unlikely to be used by patients consistently. Triple inhalers may be more expensive, may lead to long-term steroid side effects, and may be difficult to develop because of physical and chemical interactions between the three components. It will be necessary to show that the triple inhalers are significantly more effective than LABA/LAMA combinations and this is likely to be a difficult barrier to overcome.

\section{CONCLUSIONS}

There is no doubt that long-acting bronchodilators are now the mainstay of treatment for COPD patients, providing clinically meaningful improvements in symptoms, quality of life and prevention of exacerbations. There do not appear to be significant differences between individual LAMA and LABA, although a longer duration of action (once daily) is preferable in terms of stabilizing airway function. What is still unclear is whether some patients 
respond better to LAMA and others to LABA, and if so, how this can be predicted. What is also uncertain is whether there are any nonbronchodilator effects of these drugs that may be clinically relevant, such as reduced mucus secretion, increased mucociliary clearance, or anti-inflammatory or neural inhibitory effects, and this deserves further study. The value of adding an ICS to LABA/LAMA combinations is not yet clear, but some patients, such as those with increased eosinophils and asthma-COPD overlap features, may benefit from triple therapy. More research is needed to understand whether bronchodilation may be even greater with new classes of bronchodilator. It has proved very difficult to identify new classes of bronchodilator that are close to the cost-benefit provided by LABA and LAMA. Bitter taste receptor (TAS2R) agonists have been shown to relax human airways, but are less effective than $\beta_{2}$-agonists ${ }^{88,89}$. Phosphodiesterase- 3 inhibition may provide bronchodilation, but has been linked to cardiovascular side effects ${ }^{90}$. What is most needed in COPD are new anti-inflammatory therapies that are effective and safe, but this has proved to be a major challenge, and a better understanding of the underlying disease proves the need to identify new promising therapeutic targets $^{91}$.

\section{REFERENCES}

1. Cazzola M, Page CP, Calzetta L, Matera MG. Pharmacology and therapeutics of bronchodilators. Pharmacol Rev. 2012;64:450-504.

2. Guenette JA, Webb KA, O'Donnell DE. Does dynamic hyperinflation contribute to dyspnoea during exercise in patients with COPD? Eur Respir J. 2012;40:322-9.

3. Vincken W, van Noord JA, Greefhorst AP et al. Improved health outcomes in patients with COPD during $1 \mathrm{yr}$ 's treatment with tiotropium. Eur Respir J. 2002;19:209-16.

4. Korn S, Kerwin E, Atis S, Amos C, Owen R, Lassen C. Indacaterol once-daily provides superior efficacy to salmeterol twice-daily in COPD: A 12-week study. Respir Med. 2011;105:719-26.
5. Beier J, Beeh KM, Brookman L, Peachey G, Hmissi A, Pascoe S. Bronchodilator effects of indacaterol and formoterol in patients with COPD. Pulm Pharmacol Ther. 2009;22:492-6.

6. Vogelmeier C, Hederer B, Glaab $\mathrm{T}$ et al. Tiotropium versus salmeterol for the prevention of exacerbations of COPD. N Engl J Med. 2011;364:1093-103.

7. Bateman ED, Ferguson GT, Barnes N et al. Dual bronchodilation with QVA149 versus single bronchodilator therapy: the SHINE study. Eur Respir J. 2013;42:1484-94.

8. Niewoehner DE, Rice K, Cote C et al. Prevention of exacerbations of chronic obstructive pulmonary disease with tiotropium, a once-daily inhaled anticholinergic bronchodilator: a randomized trial. Ann Intern Med. 2005; 143:317-26.

9. Barnes PJ. The pharmacological properties of tiotropium. Chest. 2000;117: 63-6S.

10. Mak JCW, Barnes PJ. Autoradiographic visualization of muscarinic receptor subtypes in human and guinea pig lung. Am Rev Respir Dis. 1990;141: 1559-68.

11. Takahashi T, Belvisi MG, Patel H et al. Effect of Ba 679 BR, a novel long-acting anticholinergic agent, on cholinergic neurotransmission in guinea-pig and human airways. Am J Resp Crit Care Med. 1994;150:1640-5.

12. Brown SM, Koarai A, Sturton RG, Nicholson AG, Barnes PJ, Donnelly LE. A role for $\mathrm{M}_{2}$ and $\mathrm{M} 3$ muscarinic receptors in the contraction of rat and human small airways. Eur J Pharmacol. 2013;702:109-15.

13. Patel HJ, Barnes PJ, Takahashi T, Tadjkarimi S, Yacoub MH, Belvisi MG Characterization of prejunctional muscarinic autoreceptors in human and guinea-pig trachea in vitro. Am J Resp Crit Care Med. 1995;152:872-8.

14. Disse B, Speck GA, Rominger KL, Witek TJ, Hammer R. Tiotropium (Spiriva): mechanistical considerations and clinical profile in obstructive lung disease. Life Sci. 1999;64:457-64.

15. Barnes PJ, Belvisi MG, Mak JC, Haddad EB, O'Connor B. Tiotropium bromide (Ba $679 \mathrm{BR}$ ), a novel long-acting muscarinic antagonist for the treatment of obstructive airways disease. Life Sci. 1995;56:853-9.

16. Haddad EB, Patel H, Keeling JE, Yacoub MH, Barnes PJ, Belvisi MG. Pharmacological characterization of the muscarinic receptor antagonist, glycopyrrolate, in human and guinea-pig airways. Br J Pharmacol. 1999;127:413-20.

17. O'Donnell DE, Fluge T, Gerken F et al. Effects of tiotropium on lung hyperinflation, dyspnoea and exercise tolerance in COPD. Eur Respir J. 2004; 23:832-40.

18. Wessler I, Kirkpatrick CJ. Acetylcholine beyond neurons: the non-neuronal cholinergic system in humans. Br J Pharmacol. 2008;154:1558-71.

19. Haddad EB, Mak JC, Barnes PJ. Expression of $\beta$-adrenergic and muscarinic receptors in human lung. Am J Physiol. 1996;270:L947-53.

20. Bateman ED, Rennard S, Barnes PJ et al. Alternative mechanisms for tiotropium. Pulm Pharmacol Ther. 2009;22:533-42.

21. Koarai A, Traves SL, Fenwick PS et al. Expression of muscarinic receptors by human macrophages. Eur Respir J. 2012;49:698-704.

22. Wollin L, Pieper MP. Tiotropium bromide exerts anti-inflammatory activity in a cigarette smoke mouse model of COPD. Pulm Pharmacol Ther. 2010; 23:345-54.

23. Haag S, Matthiesen S, Juergens UR, Racke K. Muscarinic receptors mediate stimulation of collagen synthesis in human lung fibroblasts. Eur Respir J 2008;32:555-62.

24. Meurs H, Dekkers BG, Maarsingh H, Halayko AJ, Zaagsma J, Gosens R Muscarinic receptors on airway mesenchymal cells: novel findings for an ancient target. Pulm Pharmacol Ther. 2013;26:145-55.

25. Pieper MP, Chaudhary NI, Park JE. Acetylcholine-induced proliferation of fibroblasts and myofibroblasts in vitro is inhibited by tiotropium bromide. Life Sci. 2007;80:2270-3.

26. Birrell MA, Bonvini SJ, Dubuis E et al. Tiotropium modulates transient receptor potential V1 (TRPV1) in airway sensory nerves: A beneficial offtarget effect? J Allergy Clin Immunol. 2014;133:679-87.

27. Yamaya M, Nishimura H, Hatachi $Y$ et al. Inhibitory effects of tiotropium on rhinovirus infection in human airway epithelial cells. Eur Respir J. 2012;40:122-32. 
28. Cheyne L, Irvin-Sellers MJ, White J. Tiotropium versus ipratropium bromide for chronic obstructive pulmonary disease. Cochrane Database Syst Rev. 2013;CD009552.

29. O'Connor BJ, Towse LJ, Barnes PJ. Prolonged effect of tiotropium bromide on methacholine-induced bronchoconstriction in asthma. Am J Respir Crit Care Med. 1996;154:876-80.

30. Tashkin DP, Celli B, Senn S et al. A 4-year trial of tiotropium in chronic obstructive pulmonary disease. N Engl J Med. 2008;359:1543-54.

31. Decramer M, Celli B, Kesten S, Lystig T, Mehra S, Tashkin DP. Effect of tiotropium on outcomes in patients with moderate chronic obstructive pulmonary disease (UPLIFT): a prespecified subgroup analysis of a randomised controlled trial. Lancet. 2009;374:1171-8.

32. Troosters T, Celli B, Lystig $\mathrm{T}$ et al. Tiotropium as a first maintenance drug in COPD: secondary analysis of the UPLIFT trial. Eur Respir J. 2010;36: 65-73.

33. Hansel TT, Neighbour H, Erin EM et al. Glycopyrrolate causes prolonged bronchoprotection and bronchodilatation in patients with asthma. Chest. 2005;128:1974-9.

34. Kerwin E, Hebert J, Gallagher N et al. Efficacy and safety of NVA237 versus placebo and tiotropium in patients with COPD: the GLOW2 study. Eur Respir J. 2012;40:1106-14.

35. Beeh KM, Singh D, Di Scala L, Drollmann A. Once-daily NVA237 improves exercise tolerance from the first dose in patients with COPD: the GLOW3 trial. Int J Chron Obstruct Pulmon Dis. 2012;7:503-13.

36. Riario-Sforza GG, Ridolo E, Riario-Sforza E, Incorvaia C. Glycopyrronium bromide for the treatment of chronic obstructive pulmonary disease. Expert Rev Respir Med. 2015;9:23-33.

37. LaForce C, Feldman G, Spangenthal S et al. Efficacy and safety of twice-daily glycopyrrolate in patients with stable, symptomatic COPD with moderate-to-severe airflow limitation: the GEM1 study. Int J Chron Obstruct Pulmon Dis. 2016;11:1233-43.

38. Segreti A, Calzetta L, Rogliani P, Cazzola M. Umeclidinium for the treatment of chronic obstructive pulmonary disease. Expert Rev Respir Med. 2014;8:665-71.

39. Jones PW, Singh D, Bateman ED et al. Efficacy and safety of twice-daily aclidinium bromide in COPD patients: the ATTAIN study. Eur Respir J. 2012;40:830-6

40. Ni H, Soe Z, Moe S. Aclidinium bromide for stable chronic obstructive pulmonary disease. Cochrane Database Syst Rev. 2014;CD010509.

41. Singh S, Loke YK, Enright PL, Furberg CD. Mortality associated with tiotropium mist inhaler in patients with chronic obstructive pulmonary disease: systematic review and meta-analysis of randomised controlled trials. BMJ. 2011;342:d3215.

42. Wise RA, Anzueto A, Cotton D et al. Tiotropium Respimat inhaler and the risk of death in COPD. N Engl J Med. 2013;369:1491-501.

43. Johnson M, Rennard S. Alternative mechanisms for long-acting $\beta 2$-adrenergic agonists in COPD. Chest. 2001;120:258-70.

44. Dowling RB, Johnson M, Cole PJ, Wilson R. Effect of salmeterol on Haemophilus influenzae infection of respiratory mucosa in vitro. Eur Respir J. 1998;11:86-90.

45. Maneechotesuwan K, Essilfie-Quaye S, Meah S et al. Formoterol attenuates neutrophilic airway inflammation in asthma. Chest. 2005;128:1936-42.

46. Gross NJ, Donohue JF. Nebulized formoterol: a review of clinical efficacy and safety in COPD. Int J Chron Obstruct Pulmon Dis. 2010;5:223-32.

47. Donohue JF, Hanania NA, Make B et al. One-year safety and efficacy study of arformoterol tartrate in patients with moderate to severe COPD. Chest. 2014;146:1531-42

48. Zafar MA, Droege C, Foertsch M, Panos RJ. Update on ultra-long-acting beta agonists in chronic obstructive pulmonary disease. Expert Opin Investig Drugs. 2014;23:1687-701.

49. Roskell NS, Anzueto A, Hamilton A, Disse B, Becker K. Once-daily longacting beta-agonists for chronic obstructive pulmonary disease: an indirect comparison of olodaterol and indacaterol. Int J Chron Obstruct Pulmon Dis. 2014;9:813-24
50. Kew KM, Mavergames C, Walters JA. Long-acting beta2-agonists for chronic obstructive pulmonary disease. Cochrane Database Syst Rev. 2013;10 CD010177.

51. Calverley PM, Anderson JA, Celli B et al. Salmeterol and fluticasone propionate and survival in chronic obstructive pulmonary disease. N Engl J Med. 2007;356:775-89.

52. Suissa S, Ernst P, Vandemheen KL, Aaron SD. Methodological issues in therapeutic trials of COPD. Eur Respir J. 2008;31:927-33.

53. Cazzola M, Calderaro F, Califano $\mathrm{C}$ et al. Oral bambuterol compared to inhaled salmeterol in patients with partially reversible chronic obstructive pulmonary disease. Eur J Clin Pharmacol. 1999;54:829-33.

54. Vestbo J, Anderson JA, Brook RD et al. Fluticasone furoate and vilantero and survival in chronic obstructive pulmonary disease with heightened cardiovascular risk (SUMMIT): a double-blind randomised controlled trial Lancet. 2016;387:1817-26.

55. van Noord JA, Aumann JL, Janssens E et al. Comparison of tiotropium once daily, formoterol twice daily and both combined once daily in patients with COPD. Eur Respir J. 2005;26:214-22.

56. van Noord JA, Aumann JL, Janssens E et al. Combining tiotropium and salmeterol in COPD: Effects on airflow obstruction and symptoms. Respir Med. 2010;104:995-1004

57. Mahler DA, D'Urzo A, Bateman ED et al. Concurrent use of indacaterol plus tiotropium in patients with COPD provides superior bronchodilation compared with tiotropium alone: a randomised, double-blind comparison. Thorax. 2012;67:781-8.

58. van Noord JA, Buhl R, Laforce C et al. QVA149 demonstrates superior bronchodilation compared with indacaterol or placebo in patients with chronic obstructive pulmonary disease. Thorax. 2010;65:1086-91.

59. Grandordy BM, Mak JCW, Barnes PJ. Modulation of airway smooth muscle $\beta$-receptor function by a muscarinic agonist. Life Sci. 1994;54:185-91.

60. Wedzicha JA, Decramer M, Ficker JH et al. Analysis of chronic obstructive pulmonary disease exacerbations with the dual bronchodilator QVA149 compared with glycopyrronium and tiotropium (SPARK): a randomised, double-blind, parallel-group study. Lancet Respir Med. 2013;1:199-209.

61. Farne HA, Cates CJ. Long-acting beta2-agonist in addition to tiotropium versus either tiotropium or long-acting beta2-agonist alone for chronic obstructive pulmonary disease. Cochrane Database Syst Rev. 2015; CD008989.

62. de Miguel-Diez J, Jimenez-Garcia R. Considerations for new dual-acting bronchodilator treatments for chronic obstructive pulmonary disease. Exper Opin Investig Drugs. 2014;23:453-6.

63. Singh D. New combination bronchodilators for COPD: current evidence and future perspectives. Br J Clin Pharmacol. 2014;79:695-708.

64. Bateman ED, Mahler DA, Vogelmeier CF, Wedzicha JA, Patalano F, Baner ji D. Recent advances in COPD disease management with fixed-dose long-acting combination therapies. Expert Rev Respir Med. 2014;8:357-79.

65. Schlueter M, Gonzalez-Rojas N, Baldwin M, Groenke L, Voss F, Reason T. Comparative efficacy of fixed-dose combinations of long-acting muscarinic antagonists and long-acting beta2-agonists: a systematic review and network meta-analysis. Ther Adv Respir Dis. 2016;10:89-104.

66. Vogelmeier CF, Bateman ED, Pallante J et al. Efficacy and safety of oncedaily QVA149 compared with twice-daily salmeterol-fluticasone in patient with chronic obstructive pulmonary disease (ILLUMINATE): a randomised, double-blind, parallel group study. Lancet Respir Med. 2013;1:51-60.

67. Kew KM, Evans DJ, Allison DE, Boyter AC. Long-acting muscarinic antag onists (LAMA) added to inhaled corticosteroids (ICS) versus addition of long-acting beta2-agonists (LABA) for adults with asthma. Cochrane Database Syst Rev. 2015;CD011438.

68. Horita N, Miyazawa N, Tomaru K, Inoue M, Kaneko T. Long-acting muscarinic antagonist + long-acting beta agonist versus long-acting beta agonis + inhaled corticosteroid for COPD: A systematic review and meta-analysis. Respirology. 2015;20:1153-9.

69. Wedzicha JA, Banerji D, Chapman KR et al. Indacaterol-glycopyrronium versus salmeterol-fluticasone for COPD. N Engl J Med. 2016;374:2222-34. 
70. Nannini LJ, Poole P, Milan SJ, Kesterton A. Combined corticosteroid and long-acting beta(2)-agonist in one inhaler versus inhaled corticosteroids alone for chronic obstructive pulmonary disease. Cochrane Database Syst Rev. 2013;CD006826.

71. Magnussen H, Disse B, Rodriguez-Roisin R et al. Withdrawal of Inhaled Glucocorticoids and Exacerbations of COPD. N Engl J Med. 2014;371:1285-94.

72. Suissa S, Barnes PJ. Inhaled corticosteroids in COPD: the case against. Eur Respir J. 2009;34:13-16.

73. Wedzicha JA, Calverley PM, Seemungal TA, Hagan G, Ansari Z, Stockley RA. The prevention of chronic obstructive pulmonary disease exacerbations by salmeterol/fluticasone propionate or tiotropium bromide. Am J Respir Crit Care Med. 2008;177:19-26.

74. Dransfield MT, Bourbeau J, Jones PW et al. Once-daily inhaled fluticasone furoate and vilanterol versus vilanterol only for prevention of exacerbations of COPD: two replicate double-blind, parallel-group, randomised controlled trials. Lancet Respir Med. 2013;1:210-23.

75. McKeage K. Fluticasone furoate/vilanterol: a review of its use in chronic obstructive pulmonary disease. Drugs. 2014;74:1509-22.

76. Pascoe S, Locantore N, Dransfield MT, Barnes NC, Pavord ID. Blood eosinophil counts, exacerbations, and response to the addition of inhaled fluticasone furoate to vilanterol in patients with chronic obstructive pulmonary disease: a secondary analysis of data from two parallel randomised controlled trials. Lancet Respir Med. 2015;3:435-42.

77. Pavord ID, Lettis S, Locantore N et al. Blood eosinophils and inhaled corticosteroid/long-acting beta-2 agonist efficacy in COPD. Thorax. 2016; 71:118-25.

78. Hinds DR, DiSantostefano RL, Le HV, Pascoe S. Identification of responders to inhaled corticosteroids in a chronic obstructive pulmonary disease population using cluster analysis. BMJ Open. 2016;6:e010099.

79. Watz H, Tetzlaff K, Wouters EF et al. Blood eosinophil count and exacerbations in severe chronic obstructive pulmonary disease after withdrawal of inhaled corticosteroids: a post-hoc analysis of the WISDOM trial. Lancet Respir Med. 2016;4:390-8.

80. Aaron SD, Vandemheen KL, Fergusson D et al. Tiotropium in combination with placebo, salmeterol, or fluticasone-salmeterol for treatment of chronic obstructive pulmonary disease: a randomized trial. Ann Intern Med. 2007; 146:545-55.

81. Welte T, Miravitlles M, Hernandez P et al. Efficacy and tolerability of budesonide/formoterol added to tiotropium in patients with chronic obstructive pulmonary disease. Am J Respir Crit Care Med. 2009;180:741-50.
82. Rojas-Reyes MX, Garcia Morales OM, Dennis RJ, Karner C. Combination inhaled steroid and long-acting beta(2)-agonist in addition to tiotropium versus tiotropium or combination alone for chronic obstructive pulmonary disease. Cochrane Database Syst Rev. 2016;CD008532.

83. Frith PA, Thompson PJ, Ratnavadivel R et al. Glycopyrronium once-daily significantly improves lung function and health status when combined with salmeterol/fluticasone in patients with COPD: the GLISTEN study, a randomised controlled trial. Thorax. 2015;70:519-27.

84. Singh D, Schroder-Babo W, Cohuet G et al. The bronchodilator effects of extrafine glycopyrronium added to combination treatment with beclometasone dipropionate plus formoterol in COPD: A randomised crossover study (the TRIDENT study). Respir Med. 2016;114:84-90.

85. Fabbri LM, Kerwin EM, Spangenthal S, Ferguson, GT, Rodríguez-Roisin R, Pearle J, Sethi S, Orevillo C, Darken P, Rose ES, Fischer T, Golden M, Dwivedi S, Reisner C. Dose-response to inhaled glycopyrrolate delivered with a novel Co- Suspension ${ }^{\mathrm{TM}}$ Delivery Technology metered dose inhaler (MDI) in patients with moderate-to-severe COPD. Respir Research 2016; 17:109. doi: 10.1186/s12931-016-0426-4

86. Singh D, Papi A, Corradi M, Pavlišová I, Montagna I, Francisco C, Cohuet G, Vezzoli S, Scuri M, Vestbo J. Single inhaler triple therapy versus inhaled corticosteroid plus long-acting $\beta 2$-agonist therapy for chronic obstructive pulmonary disease (TRILOGY): a double-blind, parallel group, randomised controlled trial. Lancet. 2016 Sep 3;388(10048):963-73. doi: 10.1016/S0140 6736(16)31354-X. Epub 2016 Sep 1.

87. Barnes PJ. Triple inhalers for obstructive airways disease: will they be useful? Expert Rev Respir Med. 2011;5:297-300.

88. Deshpande DA, Wang WC, McIlmoyle EL et al. Bitter taste receptors on airway smooth muscle bronchodilate by localized calcium signaling and reverse obstruction. Nat Med. 2010;16:1299-304.

89. Grassin-Delyle S, Abrial C, Fayad-Kobeissi S et al. The expression and relaxant effect of bitter taste receptors in human bronchi. Respir Res. 2013; $14: 134$.

90. Franciosi LG, Diamant Z, Banner KH et al. Efficacy and safety of RPL554, a dual PDE3 and PDE4 inhibitor, in healthy volunteers and in patients with asthma or chronic obstructive pulmonary disease: findings from four clinical trials. Lancet Respir Med. 2013;1:714-727.

91. Barnes PJ. New anti-inflammatory treatments for chronic obstructive pulmonary disease. Nat Rev Drug Discov. 2013;12:543-59. 